\title{
Thrombin Receptor Activation Protects Neurons and Astrocytes from Cell Death Produced by Environmental Insults
}

\author{
Patrick J. Vaughan, ${ }^{1}$ Christian J. Pike, ${ }^{2}$ Carl W. Cotman, ${ }^{2}$ and Dennis D. Cunningham ${ }^{1}$ \\ 'Department of Microbiology and Molecular Genetics and ${ }^{2}$ Irvine Research Unit in Brain Aging, University of \\ California, Irvine, California 92717
}

Thrombin is a multifunctional serine protease that is rapidly produced from prothrombin at sites of tissue injury and catalyzes the final steps in blood coagulation. Thrombin also regulates gene expression and process outgrowth in neurons and astrocytes and stimulates proliferation of astrocytes. Since thrombin is produced immediately upon breakdown of the blood-brain barrier we examined its effects on astrocytes and neurons cultured under conditions which resemble those found in vivo following cerebrovascular injury. These studies showed that thrombin markedly protected rat primary astrocytes from cell death induced by hypoglycemia or oxidative stress. Thrombin also protected rat primary hippocampal neurons from cell death produced by hypoglycemia or growth supplement deprivation. Synthetic peptides which directly activate the thrombin receptor also protected astrocytes and neurons from these environmental insults, demonstrating that the thrombin effects were mediated through the thrombin receptor. In contrast to these results with stressed cells, high concentrations of thrombin killed both astrocytes and neurons cultured under normal conditions. All of the effects of thrombin on astrocytes and neurons were blocked by the brain thrombin inhibitor, protease nexin-1 (PN-1). This shows that the effects required the proteolytic activity of thrombin and is consistent with the known proteolytic mechanism by which thrombin activates its receptor. These results indicate that thrombin and $\mathrm{PN}-1$ may regulate the viability of both astrocytes and neurons in early moments following trauma to the CNS or other conditions that alter the blood-brain barrier.

[Key words: thrombin, receptor, neurons, astrocytes, hypoglycemia, hydrogen peroxide, cerebrovascular injury, blood-brain barrier, protease nexin-1]

Thrombin is a multifunctional serine protease which plays a ccntral role in coordinating the processes of blood coagulation, inflammation and wound repair following tissue injury. Thrombin's primary role is in the final stages of blood coagulation where it induces platelet aggregation and fibrin formation (Berndt and Phillips, 1981). In addition, thrombin regulates a

\footnotetext{
Received Dec. 22, 1994; revised Mar. 14, 1995; accepted Mar. 16, 1995.

We thank Alice Lau and Anh Do for excellent technical assistance and Jon Weinstein for critical review of the manuscript. This work was supported hy NIH Grant AG00538 to D.D.C. and C.W.C. P.J.V. was supported by a fellowship from the George E. Hewitt Foundation for Medical Research.

Correspondence should be addressed to Dennis D. Cunningham at the above address.

Copyright (C) 1995 Society for Neuroscience $\quad 0270-6474 / 95 / 155389-13 \$ 05.00 / 0$
}

number of cellular activities involved in the processes of inflammation and wound repair. For example, thrombin is chemotactic for macrophages (Bar-Shavit et al., 1983), induces the secretion of cytokines and growth factors from macrophages, smooth muscle cells, and fibroblasts (Harlan et al., 1986; Jones and Geczy, 1990; Okazaki et al., 1992) and is mitogenic for smooth muscle cells (McNamara et al., 1993) and fibroblasts (Carney et al., 1978). Since thrombin is produced immediately after injury, it is well poised to initiate cellular events that must occur early in the tissue repair program.

Recent studies have demonstrated that thrombin also regulates a number of important activities in cells of the CNS. Thrombin retracts neurites on cultured neuroblastoma cells (Gurwitz and Cunningham, 1988, 1990) and human fetal neurons (Grand et al., 1989), and converts stellate, process-bearing astrocytes to a nonstellate form exhibiting an epithelial morphology (Cavanaugh et al., 1990; Nelson and Siman, 1990). Thrombin is also mitogenic for cultured astrocytes (Perraud et al., 1987; Loret et al., 1989; Cavanaugh et al., 1990). Finally, thrombin induces the synthesis and secretion of NGF (Neveu et al., 1993) and endothelin 1 (Ehrenreich et al., 1993) from cultured astrocytes. These effects of thrombin occur at picomolar concentrations and, if controlled, have the potential to increase plasticity of the CNS and thus contribute to repair processes following cerebrovascular injury. Alternatively, excess thrombin could produce deleterious effects following injury by producing extensive retraction of processes on neurons and astrocytes and stimulating proliferation of astrocytes. The potential importance of thrombin in regulating CNS pathophysiological processes is highlighted by a recent study on the effects of directly infusing thrombin into the rat caudate nucleus (Nishino et al., 1993). This study showed that thrombin caused infiltration of inflammatory cells, proliferation of mesenchymal cells, induction of angiogenesis and an increase in reactive astrocytes. The authors of this study concluded that these changes induced by thrombin infusion resembled the inflammation, reactive gliosis and scar formation that occur after CNS injury.

The majority of the cellular activities induced by thrombin have been shown to be mediated through a novel proteolytically activated thrombin receptor (Rasmussen et al., 1991; Vu et al., 1991a). Thrombin cleaves this G-protein coupled receptor at a specific recognition sequence in the receptor's extracellular domain ( $\mathrm{Vu}$ et al., 1991b). This cleavage generates a new amino terminus which acts as a tethered peptide ligand, binding to a site on the receptor and inducing a signal transduction cascade (Vu et al., 1991a; Chen et al., 1994; Gerszlen et al., 1994). Synthetic agonist peptides corresponding to the first amino acids 
of the new amino terminus can mimic many of the cellular activities induced by thrombin (Jalink and Moolenaar, 1992; Suidan et al., 1992; Beecher et al., 1994; Grabham and Cunningham, 1995). Recent evidence has indicated that thrombin receptor mRNA is expressed by neurons and astrocytes in various regions of the rat brain, including areas that contain vulnerable neuronal populations (Niclou et al., 1994; Weinstein et al., 1995).

Like other regulatory molecules, thrombin itself must be controlled, and in the CNS this is achieved by protease nexin-1 (PN1) (Baker et al., 1980). PN-1 is identical to the glia-derived neurite promoting factor or glia-derived nexin (Guenther et al., 1985; Gloor et al., 1986; McGrogan et al., 1988) and has been shown to block or reverse the effects of thrombin on neurons and astrocytes (Guenther et al., 1985; Gurwitz and Cunningham, 1988, 1990; Cavanaugh et al., 1990; Farmer et al., 1990). PN-1 is present in distinct regions of rat (Reinhard et al., 1988, 1994) and human brain (Wagner et al., 1989) Much of the PN-1 in human brain is localized around hlood vessels (Choi et al., 1990) where it can regulate extravasated thrombin following breakdown of the blood-brain barrier. Recent studies indicate that thrombin regulation by $\mathrm{PN}-1$ is important following injury to the CNS. Several cytokines and growth factors produced in the brain following injury stimulate the synthesis and secretion of PN-1 by cultured brain cells (Cunningham al., 1993; Vaughan and Cunningham, 1993). In addition, de novo synthesis of PN 1 is triggered following transient forebrain ischemia (Hoffmann et al., 1992; Nitsch et al., 1993) and injections of excitotoxins (Scotti et al., 1994). Since PN-1 inhibits thrombin, the balance between PN-1 and thrombin may be important to optimize repair processes following cerebrovascular injury. The levels of PN-1 are reduced around cerebral blood vessels in Alzheimer's disease (Vaughan et al., 1994), suggesting that an imbalance between PN-1 and thrombin may be important in certain disease states.

Following CNS injury, brain tissue is exposed to metabolic. insults which are known to produce toxic effects on both astrocytes and neurons. The present studies were designed to better understand the regulation of CNS cells by thrombin under conditions which resemble those found in vivo following injury. These studies showed that thrombin markedly protects primary cultures of rat astrocytes and hippocampal neurons from cell death produced by several metabolic insults. In contrast, studies on astrocytes and neurons cultured under normal conditions revealed that high thrombin concentrations can kill both cell types. These results suggest important roles for thrombin in regulating the viability of astrocytes and neurons. Since thrombin is one of the first new regulatory molecules produced after injury, these effects may be important in critical early times after CNS trauma.

\section{Materials and Methods}

Materials. Highly purified human $\alpha$-thrombin (specific activity 5500 $\mathrm{NIH} \mathrm{U/mg)} \mathrm{and} \mathrm{hirudin} \mathrm{were} \mathrm{purchased} \mathrm{from} \mathrm{Calbiochem} \mathrm{(San} \mathrm{Diego,}$ $\mathrm{CA}$ ). $\mathrm{PN}-1$ was purified from serum-free medium conditioned by human foreskin fibroblasts as previously described (Van Nostrand et al., 1988). Monoclonal antibody to glial fibrillary acidic protein (GFAP) was purchased from Boehringer Mannheim (Indianapolis, IN). Monoclonal antibodies (SMI-311) to neuron-specific neurofilaments were purchased from Sternberger Monoclonals (Baltimore, MD). Peptides were synthesized by Chiron Mimotopes Peptide Systems (San Diego, CA).

Isolation of primary cultures of rat astrocytes. Primary cultures of type-1 astrocytes were prepared from the brains of 1-2 d old rat pups (Sprague-Dawley) using a modification of previously described procedures (McCarthy and de Vellis, 1980). Briefly, the frontoparietal cor- tex from cight pups was isolated, stripped of meninges, and dissociated by a combination of trypsin digestion and mechanical trituration. A single cell suspension was prepared from this dissociated tissue by passage through Nitex nylon screens. The cells were plated into six $75 \mathrm{~cm}^{2}$ plastic flasks and grown in Dulbecco's modified Eagle's medium (DMEM) containing $25 \mathrm{~mm}$ glucose, $7.5 \mathrm{~mm}$ sodium bicarbonate, 20 $\mathrm{mM}$ HEPES, $2 \mathrm{~mm}$ glutamine, $1 \mathrm{~mm}$ sodium pyruvate, $100 \mathrm{U} / \mathrm{ml}$ penicillin, $100 \mu \mathrm{g} / \mathrm{ml}$ streptomycin sulfate, and $10 \%$ fetal bovine serum. Once the cultures reached confluence (approximately 10-12 d), the flasks were shaken at $260 \mathrm{rpm}$ for $24 \mathrm{hr}$ at $37^{\circ} \mathrm{C}$ to remove nonadherent cells. After removing these nonadherent cells, the remaining type 1 astrocytes were trypsinized and reseeded into $75 \mathrm{~cm}^{2}$ flasks. Once these cells had reached confluence they were replated into 24 well dishes for experiments as detailed below. The purity of the cultures was confirmed by immunofluorescent staining with a monoclonal antibody to the type1 astroglial specific marker GFAP; $>95 \%$ of the cells were positive for this marker.

Experimental treatment of astrocytes. Astrocytes were removed from flasks by trypsinization and plated at a density of $7 \times 10^{4}$ cells $/ \mathrm{cm}^{2}$. After growth to $70-80 \%$ confluence ( $2-3 \mathrm{~d}$ after plating), the cells were used in experiments. In all experiments cells were rinsed three times with serum-free medium containing $25 \mathrm{~mm}$ glucose and then incubated in the same medium for $16-18 \mathrm{hr}$ prior to experimental treatments. In some cases, as detailed in the text, the cells were differentiated by the inclusion of $1.5 \mathrm{~mm}$ dibutyryl cyclic AMP ( $\mathrm{dbcAMP}$ ) which was then maintained in all media throughout the experiment. For experiments involving glucose deprivation, cells were rinsed three times in medium containing $0.5 \mathrm{~mm}$ glucose and then incubated in either reduced glucose medium alone or reduced glucose medium containing the indicated concentrations of thrombin or the thrombin receptor activating peptide, SFLLRN. Cell viability was determined $48 \mathrm{hr}$ following additions. For experiments involving hydrogen peroxide treatment, cells were rinsed in medium containing $25 \mathrm{~mm}$ glucose and then incubated in this medium alone or medium containing the indicated concentrations of thrombin or the thrombin receptor activating peptide. Twenty-four hours later, hydrogen peroxide was added to a final concentration of $100 \mu \mathrm{M}$. Twenty-four hours after the addition of hydrogen peroxide, cell viability was determined. For experiments involving the effects of thrombin on cell viability under normal culture conditions, cells were rinsed three times in medium containing $25 \mathrm{~mm}$ glucose and then incubated in either medium alone or medium containing the indicated concentrations of thrombin. Cell viability was determined $72 \mathrm{hr}$ after the addition of thrombin. In all experiments, cell viability was calculated relative to control cultures which were maintained in medium containing $25 \mathrm{~mm}$ glucose throughout the experiment. In experiments involving the inhibition of thrombin activity, thrombin was incubated in the absence or presence of a 10-fold molar excess of hirudin or PN-1 for $30 \mathrm{~min}$ at $37^{\circ} \mathrm{C}$ prior to addition to cells.

In experiments examining the effects of thrombin on cells cultured under normal and reduced glucose conditions, cell viability was determined by assaying the medium from each well for lactate dehydrogenase (LDH) activity using a diagnostic kit according to the manufacturer's instructions (Sigma, St. Louis, MO). Released LDH is a stable enzymatic marker that correlates linearly with cell death. The total activity of LDH in control cultures was considered to represent $100 \%$ cell viability. This was determined by measuring $\mathrm{LDH}$ activity in the culture medium plus LDH activity released from cells after treatment with $0.5 \%$ Triton X-100. In experiments examining the effects of thrombin on hydrogen peroxide treatment, cell viability, was determined based on the number of cells excluding $0.2 \%$ trypan blue dye since hydrogen peroxide interferes with the LDH assay. The total number of cells in control cultures was considered to represent $100 \%$ cell viability. In some experiments, $2 \mu \mathrm{g} / \mathrm{ml}$ of ethidium homodimer (Molecular Probes) was added to the control and thrombin-treated cultures to monitor viability microscopically. All results are expressed as the mean \pm SEM of triplicate samples. All studies were repeated in at least three independent experiments.

Isolation of rat hippocampal neurons. Hippocampal neuronal cultures were prepared as previously described (Pike et al., 1993). Briefly, hippocampi were dissected from embryonic day 18 Sprague-Dawley rat pups and mechanically dissociated in a $\mathrm{Ca}^{2+} / \mathrm{Mg}^{2+}$-free balanced salt solution. The cell suspension was briefly washed in 2 volumes of medium supplemented with $10 \%$ fetal bovine serum, then pelleted and resuspended in serum-free DMEM containing $25 \mathrm{mM}$ glucose, $26 \mathrm{mM}$ sodium bicarbonate, $20 \mathrm{~mm}$ HEPES, $1 \mathrm{~mm}$ pyruvate and supplemented 
with $\mathrm{N} 2$ components ( $30 \mathrm{nM}$ selenium, $20 \mathrm{nM}$ progesterone, $100 \mu \mathrm{M}$ putrescine, $100 \mu \mathrm{g} / \mathrm{ml}$ transferrin, and $5 \mu \mathrm{g} / \mathrm{ml}$ bovine insulin) (Bottenstein and Sato, 1979). The purity of the cultures was confirmed using monoclonal antibodies against neuronal-specific neurofilaments (Sternberger Monoclonals); $>95 \%$ of the cells were positive for this marker (Pike et al., 1993).

Experimental treatment of rat hippocampal neurons. Neurons were plated into 48-well dishes at a density of $2.5 \times 10^{4}$ cells $/ \mathrm{cm}^{2}$. For glucose deprivation experiments, cells that had been cultured in DMEM/N2 for $1-3 \mathrm{~d}$ following isolation were switched to the low glucose condition by three rinses (each at $80 \%$ of well volume) with glucose-free medium to give a final concentration of $0.2 \mathrm{~mm}$ glucose Following medium shifting, thrombin was added immediately and cell viability was determined when widespread degeneration was apparent in the low glucose/no thrombin condition $(2-4 \mathrm{~d}$ later $)$. For the N2 supplement deprivation experiments, freshly isolated neurons were plated in medium in the absence of the N2 supplements. Thrombin was added $1 \mathrm{hr}$ after plating and cell viability determined $48 \mathrm{hr}$ later. To analyze the effects of thrombin on cell viability under normal culture conditions, thrombin was added to neurons that had been cultured in DMEM with $\mathrm{N} 2$ supplements for $24 \mathrm{hr}$ following isolation. Cell viability was determined $48 \mathrm{hr}$ later. Neuronal viability was determined based on the number of cells excluding $0.2 \%$ trypan blue and/or exhibiting positive staining for the viability dye calcein AM and negative staining for ethidium homodimer (Molecular Probes, Eugene, OR). The total number of cells was considered to represent $100 \%$ cell viability. All results are expressed as the mean \pm SEM of triplicate samples. All studies were repeated in at least three independent experiments.

\section{Results}

Thrombin protects astrocytes against cell death induced by hypoglycemia

Since thrombin is produced immediately following injury and regulates a number of activities of cultured astrocytes which may be involved in CNS repair processes, we examined the effects of thrombin on cells cultured under conditions that resemble those found in vivo following injury. The first condition examined was hypoglycemia. All experiments were conducted under serum-free conditions. Primary cultures of postnatal rat astrocytes were first differentiated into a stellate morphology by treatment with dbcAMP for $24 \mathrm{hr}$. The cells were then incubated in medium containing $0.5 \mathrm{~mm}$ glucose in the absence or presence of $10 \mathrm{nM}$ thrombin. Control cultures were maintained in medium containing normal glucose concentrations $(25 \mathrm{~mm})$. Forty-eight hours following exposure to hypoglycemic conditions, cell viability was monitored by the addition of ethidium homodimer, a fluorescent dye specifically taken up by dead cells (Fig. 1). As expected, control cultures exposed to dbcAMP for $48 \mathrm{hr}$ exhibited a stellate, process-bearing morphology and did not exhibit a significant loss in cell viability (Fig. $1 A, B$ ). In cultures exposed to hypoglycemic conditions for $48 \mathrm{hr}$ the majority of the cells exhibited clear signs of morphological degeneration and cell death (Fig. 1C,D). However, cultures exposed to hypoglycemic conditions in the presence of $10 \mathrm{nM}$ thrombin were protected against hypoglycemia-induced damage (Fig. $1 E, F$ ); cell viability in these cultures was similar to that of control cultures (compare Fig. $(B, F)$. It should be noted that in addition to its protective effect, thrombin converted the stellate process-bearing astrocytes to a flattened epithelial-like morphology as previously reported (compare Fig. 1A,E) (Cavanaugh et al., 1990). (It should be noted that thrombin failed to protect undifferentiated astrocytes cultured under hypoglycemic conditions. Thrombin also failed to protect undifferentiated fibroblasts cultured under hypoglycemic conditions. The significance of this difference is presently under investigation).

To quantitate the protective effect of thrombin, astrocytes were incubated under hypoglycemic conditions in the absence or presence of various concentrations of thrombin. Forty-eight hours later, cell viability in each culture was determined by measuring release of $\mathrm{I} . \mathrm{DH}$ into the medium. (Measurements of cell viability in parallel cultures by trypan blue dye exclusion assays gave similar results). Control cultures were $>95 \%$ viable after $48 \mathrm{hr}$. As shown in Figure $2 A$, astrocytes cultured under hypoglycemic conditions underwent cell death and only $15-20 \%$ of the cells were viable after $48 \mathrm{hr}$. However, addition of thrombin at the time cells were switched to the hypoglycemic conditions produced a marked protective effect over a broad range of concentrations. At optimal concentrations of thrombin (10 pM to 10 $\mathrm{nM}), 60-70 \%$ of the astrocytes were viable after $48 \mathrm{hr}$. It is noteworthy that at the highest concentrations tested $(100 \mathrm{nM}$ and $1 \mu \mathrm{M})$, the protective effect of thrombin was less pronounced. This result suggests that regulation of thrombin activity may be important to achieve optimal protection. It should be noted that during the $48 \mathrm{hr}$ incubation period, thrombin had no significant effect on cell number at any of the concentrations tested. The protective effect at all concentrations of thrombin was blocked by the thrombin inhibitors hirudin and PN-1, indicating that this effect required the proteolytic activity of thrombin (data not shown).

To determine if the protective effect of thrombin was receptor mediated, identical experiments were conducted in which the thrombin receptor activating peptide, SFLLRN, was substituted for thrombin. As a control we used a scrambled peptide, FSLLRN, which is unable to activate the thrombin receptor ( $\mathrm{Vu}$ et al., 1991a). Cell viability was determined $48 \mathrm{hr}$ following exposure to hypoglycemic conditions (Fig. 2B). As shown, SFLLRN produced a marked protective effect over a range of concentrations, with optimal protection occurring at $100 \mathrm{~nm}$ to $100 \mu \mathrm{M}$. The scrambled peptide FSLLRN failed to elicit a protcetive effect at any of the concentrations tested. The level of protection induced by SFLLRN was similar to that elicited by optimal concentrations of thrombin, indicating that activation of the thrombin receptor was sufficient to induce a full protective effect. It should be noted that much higher concentrations of peptide than thrombin were required to produce the same protective effect. Similar differences have been found with other cellular effects mediated by thrombin and thrombin receptor activating peptides (Hung et al., 1992; Beecher et al., 1994).

\section{Thrombin protects astrocytes against cell death induced by hydrogen peroxide}

To determine if thrombin would protect cells against other insults, particularly ones that may act near the final stages of cell death, we examined the effects of thrombin on cells subjected to oxidative stress mediated by hydrogen peroxide. Rat astrocytes were first incubated under serum-free conditions for $24 \mathrm{hr}$ in the presence of dbcAMP (differentiated cells) or absence of dbcAMP (undifferentiated cells). The cells were then incubated in the absence or presence of $10 \mathrm{nM}$ thrombin for $24 \mathrm{hr}$ prior to addition of $100 \mu \mathrm{M}$ hydrogen peroxide. Twenty-four hours following the insult, cell viability was monitored by addition of ethidium homodimer to the cells (Figs. 3,4). Control cultures were maintained in medium (minus or plus dbcAMP) without hydrogen peroxide or thrombin treatment and did not exhibit a significant loss in cell viability after $48 \mathrm{hr}$ (Figs. $3 A, B ; 4 A, B$ ). Hydrogen peroxide induced widespread morphological degeneration and cell death of both differentiated (Fig. 3C,D) and undifferentiated (Fig. 4C,D) astrocytes. Pretreatment of these cultures with $10 \mathrm{nM}$ thrombin protected both undifferentiated 

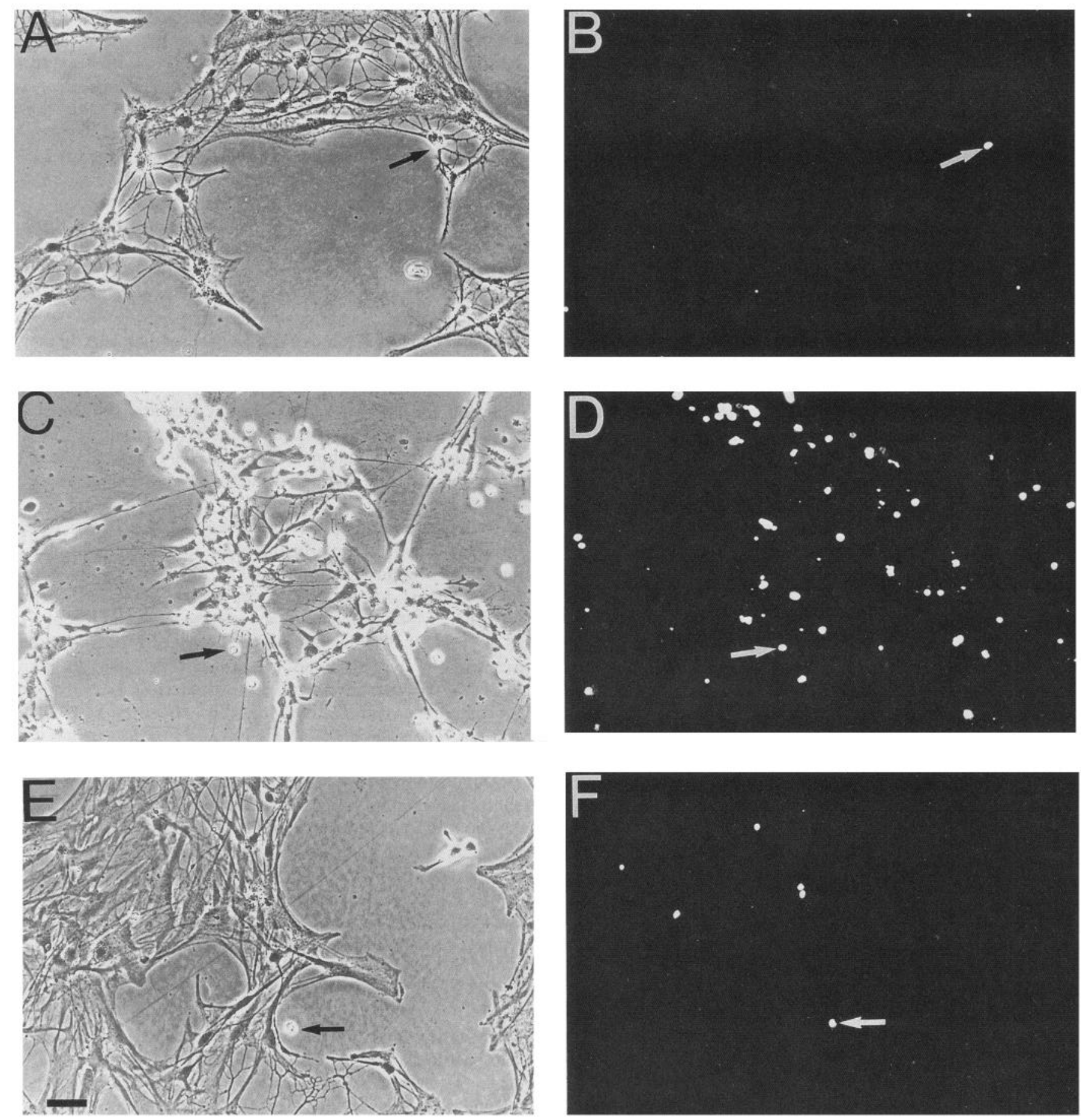

Figure 1. Thrombin protects rat astrocytes from cell death produced by hypoglycemia. Rat astrocytes were incubated in medium containing 25 $\mathrm{mm}$ glucose $(A$ and $B$, control), $0.5 \mathrm{~mm}$ glucose $(C$ and $D)$ or $0.5 \mathrm{~mm}$ glucose plus $10 \mathrm{~nm}$ thrombin $(E$ and $F)$. After 48 hr cell viability was monitored by the addition of ethidium homodimer. $A, C$, and $E$ show the phase-contrast images of cell cultures and $B, D$ and $F$ show the corresponding fluorescent image of the same field. The arrows indicate cells that exhibit signs of morphological degeneration and cell death. Scale bar, $20 \mu \mathrm{m}$.

and differentiated astrocytes from cell death induced by hydrogen peroxide (Figs. $3 E, F ; 4 E, F$ ).

To quantitate the protective effect of thrombin against the toxic effect of hydrogen peroxide, differentiated and undifferentiated astrocytes were pretreated with various concentrations of thrombin for $24 \mathrm{hr}$ prior to the addition of $100 \mu \mathrm{M}$ hydrogen peroxide. Cell viability was then determined $24 \mathrm{hr}$ following the insult (Fig. 5A). Control cultures were greater than $95 \%$ viable after 72 hr. As shown in Figure 5A, approximately $100 \%$ of differentiated and undifferentiated astrocytes were killed following exposure to $100 \mu \mathrm{M}$ hydrogen peroxide for $24 \mathrm{hr}$. Pretreatment of differentiated and undifferentiated astrocytes with thrombin for $24 \mathrm{hr}$ induced a pronounced protective effect against hydrogen peroxide-induced death over a wide range of 
A
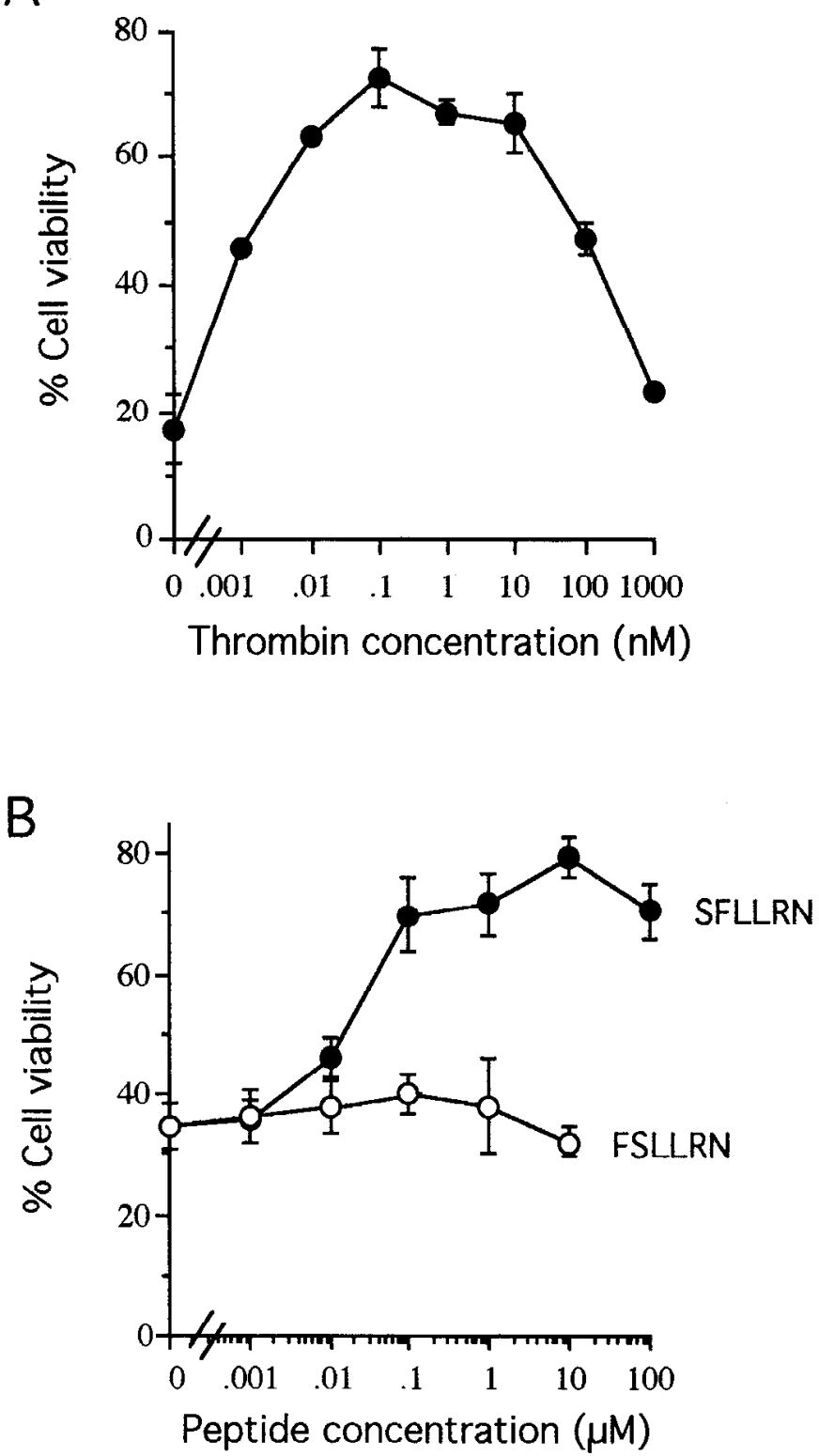

Figure 2. Thrombin and thrombin receptor activating peptide prolect astrocytes from cell death produced by hypoglycemia. $A$, Dose-response curve for the protective effect of thrombin. Rat astrocytes were incubated in medium containing $0.5 \mathrm{~mm}$ glucose in the absence or presence of the indicated concentrations of thrombin. After $48 \mathrm{hr}$, cell viability was determined by measuring the release of LDH into the medium. $B$, Dose-response curve for the protective effect of thrombin receptor activating peptide. Rat astrocytes were treated as described for $A$ except that the thrombin receptor activating peptide, SFI.I.RN (O) or scrambled peptide, FSLLRN $(O)$, were substituted for thrombin. All values are expressed as the mean \pm SEM. All studies were repeated in at least three independent experiments.

thrombin concentrations. Optimal concentrations of $100 \mathrm{pM}$ to $100 \mathrm{~nm}$ thrombin protected $70-80 \%$ of differentiated and 90 $100 \%$ of undifferentiated astrocytes against hydrogen peroxideinduced cell death. At the highest concentration of thrombin tested $(1 \mu \mathrm{M})$, the protective effect of thrombin was less pronounced. Although the reduction in thrombin's protective effect at $1 \mu \mathrm{M}$ was small, it was highly reproducible between separate experiments.

Since thrombin exhibited a more robust protective effect on undifferentiated astrocytes, subsequent experiments were conducted on undifferentiated astrocytes. To determine if the protective effect of thrombin against hydrogen peroxide-induced death was mediated through the thrombin receptor, similar experiments were conducted in which the thrombin receptor activaling peptide SFLLRN was substituted for thrombin (Fig. 5B). At concentrations of $10 \mu \mathrm{M}$ and $100 \mu \mathrm{M}$ SFLLRN induced a marked protective effect against hydrogen peroxide-induced killing. In contrast, the same concentrations of the scrambled peptide FSLLRN failed to elicit a significant protective effect. The degree of protection conferred by $100 \mu \mathrm{M}$ SFLLRN was similar to that induced by optimal concentrations of thrombin.

Since thrombin is produced immediately after injury, its effects might be important in very early stages of repair processes. To test this hypothesis, we detcrmined the thrombin pretreatment time required to confer protection of astrocytes against hydrogen peroxide-mediated killing. Astrocytes were treated with $100 \mathrm{nM}$ thrombin for various times prior to or following the addition of $100 \mu \mathrm{M}$ hydrogen peroxide. Thrombin was maintained in the cultures throughout the duration of the hydrogen peroxide treatment. Twenty-four hours following addition of hydrogen peroxide, cell viability was determined (Fig. 5C). Thrombin conferred nearly complete protection against the killing effect of hydrogen peroxide when added at any time up to $1 \mathrm{hr}$ prior to the insult. When thrombin was added at the time of the insult, $60-70 \%$ of the astrocytes still survived hydrogen peroxide treatment, significantly higher than the $7 \%$ survival rate in cultures which were incubated without thrombin. When added $1 \mathrm{hr}$ following the insult, thrombin failed to elicit a significant protective effect (Fig. 5C). It should be noted that although cell viability was measured $24 \mathrm{hr}$ following the addition of hydrogen peroxide, cell death was evident within $1 \mathrm{hr}$ of the insult (data not shown). These results demonstrated that the protective effect of thrombin was induced rapidly.

\section{Thrombin protects rat hippocampal neurons from cell death induced by hypoglycemia}

In view of the protective effects of thrombin on astrocytes, we determined if thrombin protected neurons against metabolic insults. The following experiments were conducted on cultures of rat hippocampal neurons that had been maintained in serum-free medium with $\mathrm{N} 2$ supplements for 1-3 d after isolation. We first examined effects of thrombin on cells incubated under hypoglycemic conditions. Cells were incubated in medium containing 0.2 $\mathrm{mm}$ glucose in the absence or presence of $100 \mathrm{~nm}$ thrombin. Forty-eight hours later, cell viability was monitored by phase contrast microscopy (Fig. 6A-C). Control cultures incubatcd in medium containing normal glucose concentrations did not exhibit significant loss of cell viability after $48 \mathrm{hr}$ (Fig. 6A). In cultures that had been incubated under hypoglycemic conditions, the majority of neurons showed clear signs of morphological degeneration and cell death, as indicated by the fragmented appearance of neurites and irregularly shaped soma (Fig. 6B). However, neurons that were exposed to hypoglycemic conditions in the presence of 100 nM thrombin were protected against hypoglycemic-induced death; cells in these cultures had smooth, oval shaped soma and intact neurites (Fig. 6C). Cell viability in thrombin-treated cultures was similar to that of control cultures (compare Fig. 6A,C). Although thrombin induces extensive neurite retraction in several neuroblastoma and neuronal cell types, it induced only minor retraction of neurites on rat hippocampal neurons.

To quantitate the protective effect of thrombin against cell death 

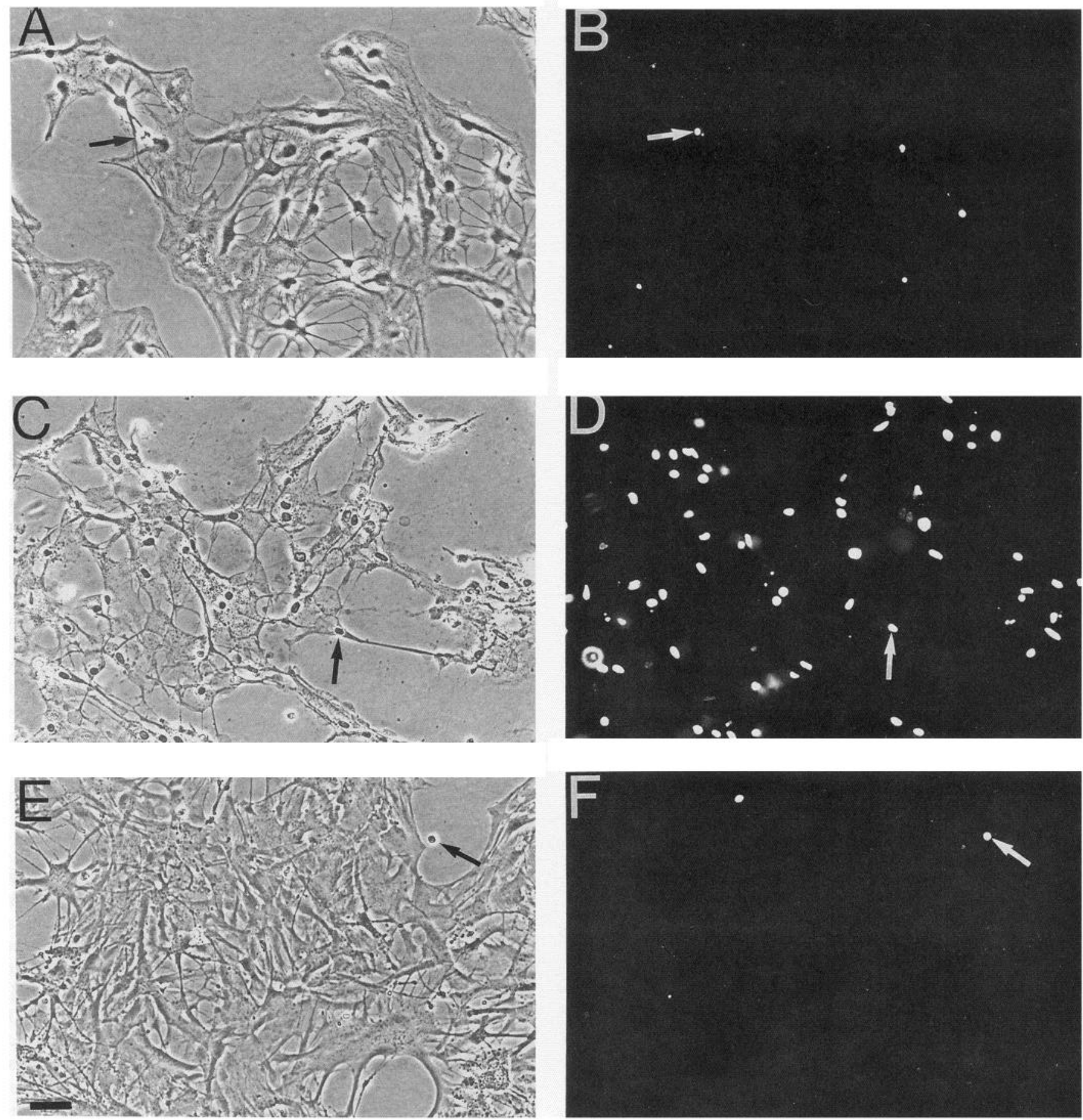

Figure 3. Thrombin protects differentiated astrocytes from cell death produced by hydrogen peroxide. Differentiated rat astrocytes were incubated in medium in the absence or presence of $10 \mathrm{nM}$ thrombin for $24 \mathrm{hr}$ prior to the addition of $100 \mu \mathrm{M}$ hydrogen peroxide. Twenty-four hours after the addition of hydrogen peroxide cell viability was monitored by the addition of ethidium homodimer to the cells. $A$ and $B$, Medium alone; $C$ and $D$, medium plus $100 \mu \mathrm{M}$ hydrogen peroxide; $E$ and $F$, medium plus $100 \mu \mathrm{M}$ hydrogen peroxide in the presence of $10 \mathrm{~nm}$ thrombin. $A, C$, and $E$ show phase contrast images, and panels $B, D$, and $F$ the corresponding fluorescent image of the same field. The arrows indicate cells that exhibit signs of morphological degeneration and cell death. Scale bar, $20 \mu \mathrm{m}$.

induced by hypoglycemia, neurons were incubated under hypoglycemic conditions in the absence or presence of various concentrations of thrombin. Forty-eight hours later cell viability was determined using the viability dye calcein $\mathrm{AM}$ and ethidium homodimer (Fig. $7 A$ ). Control cultures were $>95 \%$ viable after $48 \mathrm{hr}$. Neurons cultured under hypoglycemic conditions underwent massive cell death and contained less than $1 \%$ viable cells after 48 hr. Addition of thrombin at the time cells were switched to hypoglycemic conditions produced a dramatic protective effect at concentrations of $100 \mathrm{~nm}$ and $1 \mu \mathrm{M}$. At a concentration of 100 nM thrombin protected $100 \%$ of neurons from hypoglycemic-induced cell death. At the highest concentration tested, $1 \mu \mathrm{M}$, the protective effect was less pronounced. It should be noted that the concentration of thrombin required to elicit a protective effect 

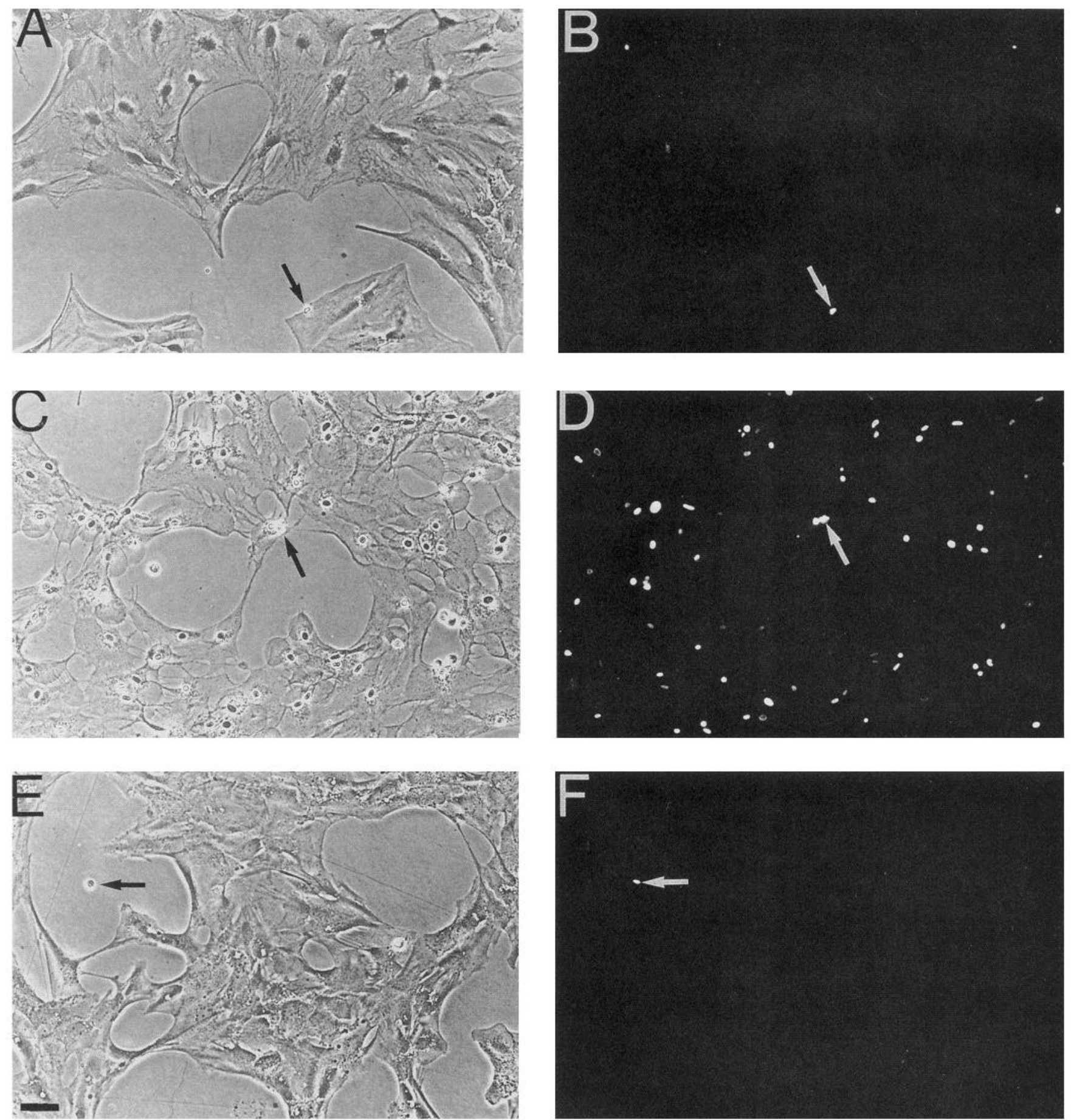

Figure 4. Thrombin protects undifferentiated astrocytes from cell death produced by hydrogen peroxide. Undifferentiated astrocytes were treated exactly as described in the Figure 3 caption. $A$, Medium alone; $C$ and $D$, medium plus $100 \mu \mathrm{M}$ hydrogen peroxide; medium plus $100 \mu \mathrm{m}$ hydrogen peroxide in the presence of $10 \mathrm{nM}$ thrombin. $A, C$, and $E$ are the phase contrast images and $B, D$, and $F$ are the corresponding fluorescent images of the same field. The arrows indicate cells that exhibit signs of morphological degeneration and cell death. Scale bar, $20 \mu \mathrm{m}$.

against hypoglycemia was higher for neurons than for astrocytes (compare Figs. $2 A, 7 A$ ), although the reason for this difference is not clear. The hypoglycemic experiments described above were conducted on cells cultured in the absence or presence of N2 supplements and similar results were obtained (data not shown). These experiments were conducted on neurons that had been in culture for only 1-3 d and had not yet developed a mature phenotype. To determine if the response to thrombin was similar in more differentiated neurons, similar experiments were conducted on neurons that had been in culture for $7 \mathrm{~d}$ prior to experimental treatment; similar results were obtained (data not shown).

Thrombin protects rat hippocampal neurons from cell death induced by growth supplement deprivation

In view of the above robust protective effects of thrombin, we determined if it could prevent cell death in neurons deprived of 
A

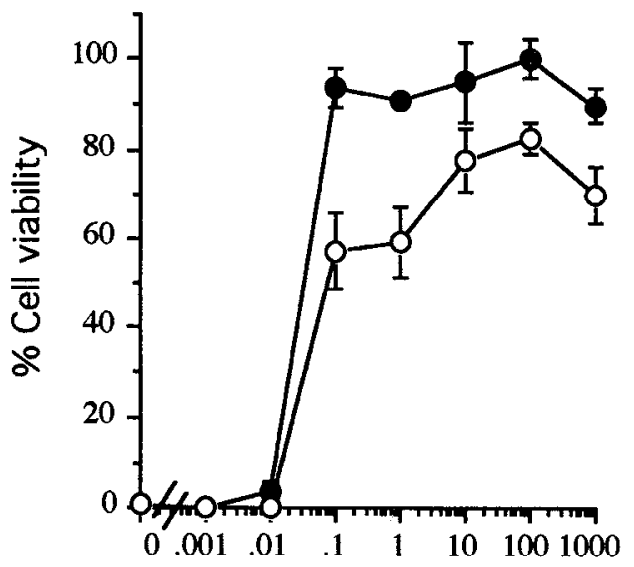

B
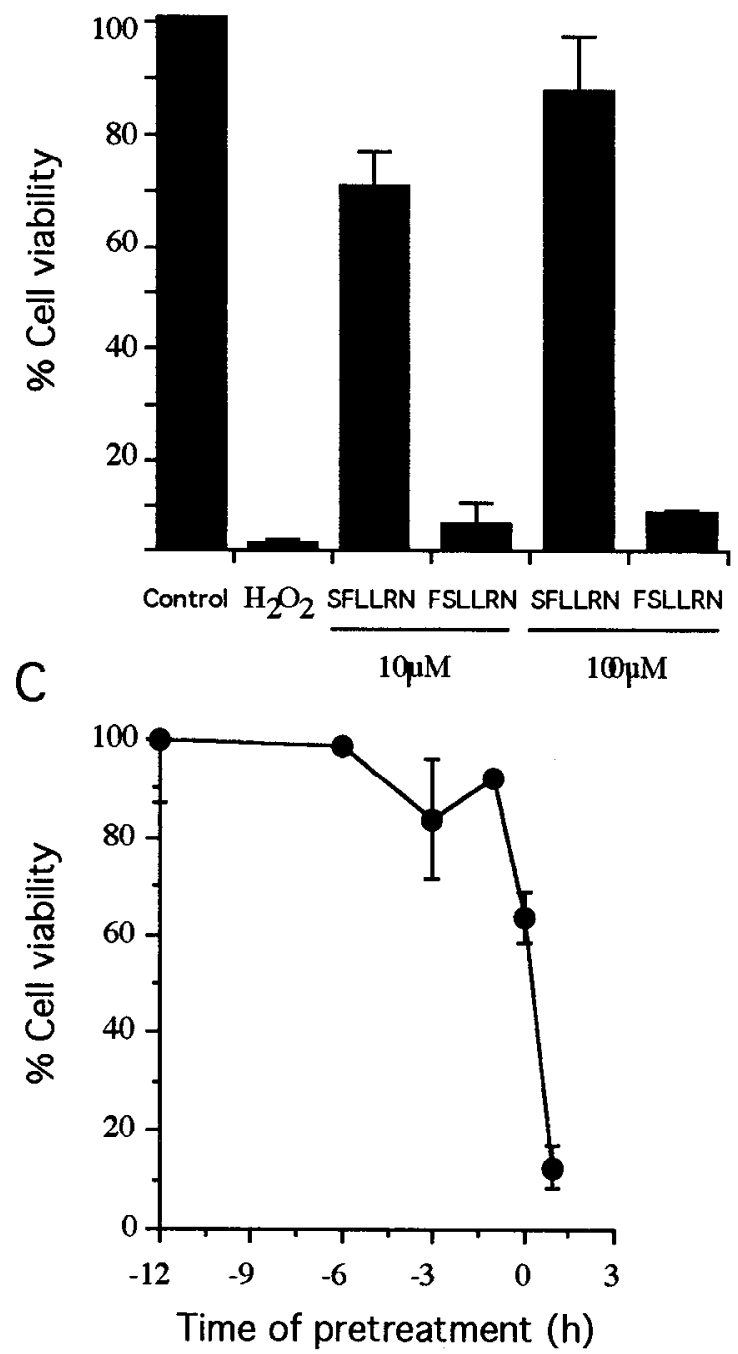

Figure 5. Thrombin and the thrombin receptor activating peptide protect rat astrocytes from cell death produced by hydrogen peroxide. $A$, Dose response curve for thrombin. Differentiated $(O)$ and undifferentiated (O) rat astrocytes were incubated in the absence or presence of the indicated concentrations of thrombin for $24 \mathrm{hr}$ prior to the addition of $100 \mu \mathrm{M}$ hydrogen peroxide. Twenty-four hours after the addition of hydrogen peroxide, cell viability was determined by trypan blue dye exclusion. $B$, Protective effect of the thrombin receptor activating peptide. Undifferentiated astrocytes were incubated in the absence or pres- growth supplements. This was facilitated by the finding that $\mathrm{N} 2$ supplements were necessary to establish cultures of freshly isolated neurons. If neurons that were freshly isolated from the brain were plated in the absence of $\mathrm{N} 2$ supplements, they underwent a significant loss in cell viability. To determine if thrombin could protect these cells, we added various concentrations of thrombin $1 \mathrm{hr}$ after plating and determined cell viability 48 hr later (Fig. 7B). Control cultures were plated in medium containing N2 supplements and were $>95 \%$ viable after $48 \mathrm{hr}$. Cultures plated in medium lacking N2 supplements contained approximately $25 \%$ viable neurons after $48 \mathrm{hr}$. Addition of thrombin at a concentration of $100 \mathrm{nM}$ to $1 \mu \mathrm{M}$ induced significant protection against cell death which occurred in the absence of $\mathrm{N} 2$ supplements. At a concentration of $100-500 \mathrm{nM}$, thrombin increased cell survival to approximately $80-90 \%$. At the highest concentration of thrombin tested, $1 \mu \mathrm{M}$, the protective effect of thrombin was less pronounced. The protective effects of thrombin on neuronal cells were blocked by the specific thrombin inhibitors hirudin and PN-1 (data not shown). (It should be noted that a loss of neuron viability was not observed for 48-72 hr when $\mathrm{N} 2$ was removed following establishment of cultures in the presence of $\mathrm{N} 2$ as in the hypoglycemia experiments).

To determine if the neuroprotective effects of thrombin were receptor-mediated, similar experiments to those described above were conducted in which the thrombin receptor activating peptide SFLLRN was substituted for thrombin. SFLLRN induced a significant protective effect against cell death (Fig. 7C). In contrast, the scrambled peptide FSI I,RN failed to elicit a significant protective effect. The degree of protection conferred by $1 \mathrm{mM}$ SFLLRN was similar to that induced by optimal concentrations of thrombin (compare Fig. 7B,C).

\section{Thrombin kills astrocytes and neurons cultured under normal conditions}

Expcriments were also conducted to evaluate effects of thrombin on the viability of astrocytes and neurons cultured under normal conditions. Differentiated and undifferentiated astrocytes were incubated in medium containing normal glucose concentrations in the absence or presence of various concentrations of thrombin. After $72 \mathrm{hr}$, cell viability was determined by measuring the release of LDH (Fig. 8A). As shown, in the absence of thrombin, approximately $95 \%$ of undifferentiated and $75 \%$ of differentiated astrocytes survived after $72 \mathrm{hr}$. Thrombin killed both differentiated and undifferentiated astrocytes at concentrations of $>500$ $\mathrm{nM}$, with only $20 \%$ of astrocytes surviving at $1 \mu \mathrm{M}$ thrombin.

Similar experiments were conducted on rat hippocampal neurons. Neurons were plated in medium containing normal glucose concentrations and N2 supplements. Twenty-four hours after plating, the cells were treated with various concentrations of

$\leftarrow$

ence of the indicated concentrations of peptide SFLLRN or FSLLRN for $24 \mathrm{hr}$ prior to the addition of $100 \mu \mathrm{M}$ hydrogen peroxide. Control cultures were maintained in medium without hydrogen peroxide or thrombin treatment throughout the experiment. $C$, Time of thrombin pretreatment required to confer protection. Undifferentiated astrocytes were treated with $100 \mathrm{~nm}$ thrombin at the indicated times prior to or following the addition of hydrogen peroxide. Cell viability was deter mined $24 \mathrm{hr}$ following the addition of hydrogen peroxide. Cell viability of cultures that were treated with hydrogen peroxide in the absence of thrombin was $7.1 \% \pm 2.6$. All values are expressed as the mean \pm SEM of triplicate samples. All studies were repeated in at least three independent experiments. 

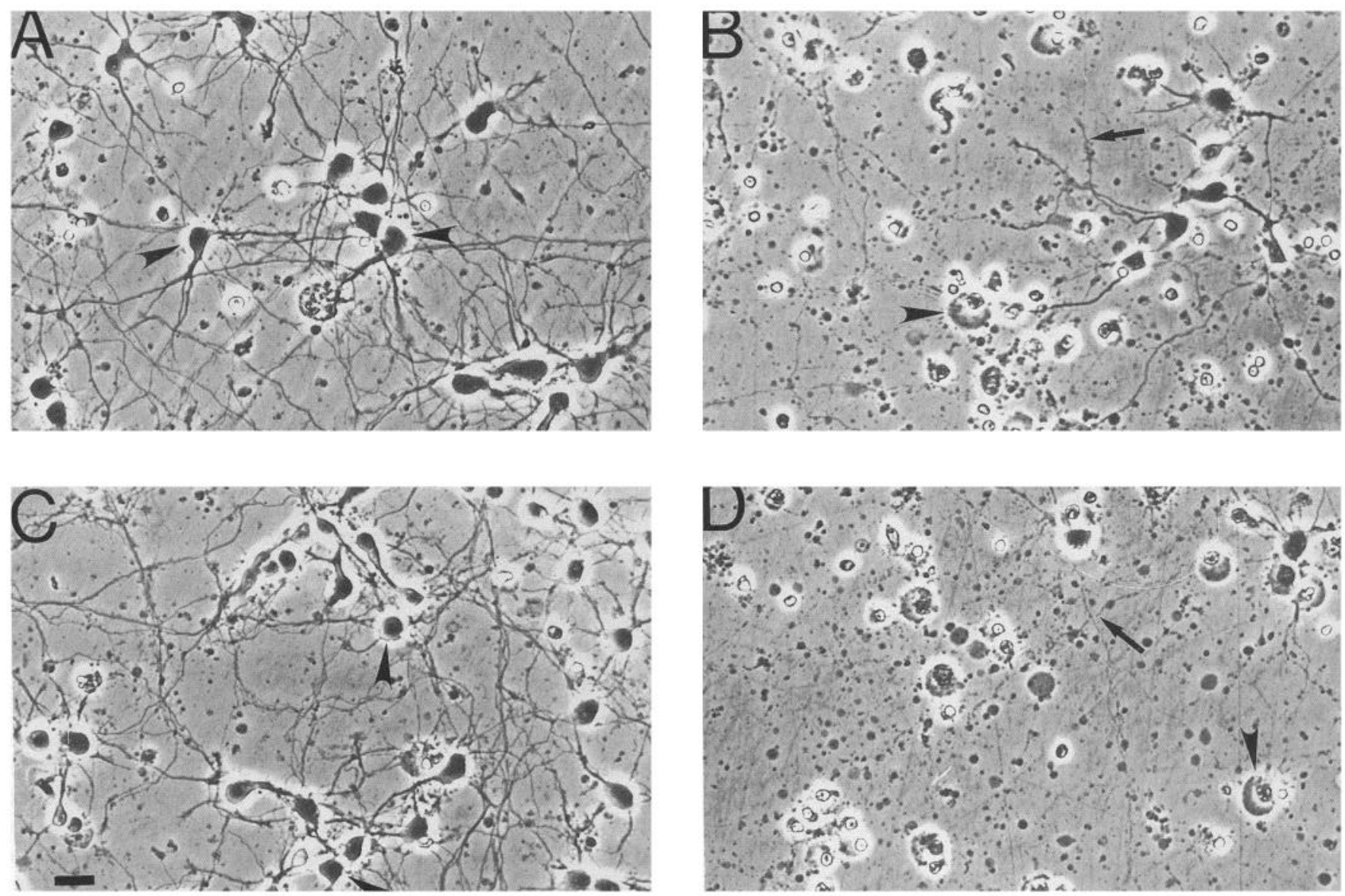

Figure 6. Thrombin protects rat hippocampal neurons from cell death mediated by hypoglycemia and kills neurons cultured under normal conditions. Rat hippocampal neurons were incubated in medium containing $25 \mathrm{~mm}$ glucose $(A), 0.2 \mathrm{~mm}$ glucose $(B), 0.2 \mathrm{~mm}$ glucose plus $100 \mathrm{nM}$ thrombin $(C)$ or $25 \mathrm{~mm}$ glucose plus $1 \mu \mathrm{M}$ thrombin $(D)$. After $48 \mathrm{hr}$ cell viability was determined by phase contrast microscopy. In $B$ and $D$, neurons undergoing cell death are indicated by the fragmented appearance of neurites (arrows) and swollen irregular shaped soma (arrowheads). In $A$ and $C$, viable neurons are indicated by smooth oval shaped soma (arrowheads). Scale bar, $50 \mu \mathrm{m}$.

thrombin and cell viability determined $48 \mathrm{hr}$ later (Fig. $8 B$ ). Control cultures were $>95 \%$ viable after $48 \mathrm{hr}$. At concentrations of $>500 \mathrm{nM}$, thrombin induced a significant killing of neurons, with only $20 \%$ of neurons surviving at $1 \mu \mathrm{M}$ thrombin (Fig. $8 B$ ). The morphological appearance of control and thrombin-treated neurons is shown in Figure $6, A$ and $D$. Control cultures did not exhibit a significant loss of cell viability after 48 hr (Fig. 6A). In contrast, the majority of neurons treated with 1 $\mu \mathrm{M}$ thrombin exhibited clear signs of morphological degeneration and cell death (Fig. $6 D$ ). It should be noted that high concentrations of thrombin $(500 \mathrm{nM}$ and $1 \mu \mathrm{M})$ killed neurons and astrocytes cultured under normal conditions but protected astrocytes and neurons that were cultured under conditions of stress (compare, e.g., Figs. $2 A, 8 A$; Figs. $7 A, 8 B$ ). Due to the high concentrations of thrombin required to kill astrocytes and neurons and the solubility constraints of the peptides, it was not possible to achieve concentrations of the thrombin receptor activating peptide sufficient to determine if the killing effect was receptor mediated. However, the killing effects of thrombin on astrocytes and neurons were blocked by hirudin and PN-1, indicating that this effect required the proteolytic activity of thrombin (data not shown).

\section{Discussion}

The present results along with previous studies suggest that thrombin may help to control general repair programs in the
CNS following trauma (Perraud et al., 1987; Gurwitz and Cunningham, 1988; Cavanaugh et al., 1990; Nishino et al., 1993). Breakdown of the blood-brain barrier leads to extravasation of prothrombin which provides an immediate source of thrombin upon contact with brain tissue following injury (Mann, 1987). The present finding that thrombin regulates the viability of both astrocytes and neurons strengthens the hypothesis that it may trigger programs whose early activation is crucial for survival and subsequent repair. On the other hand, excess thrombin may inhibit repair processes and damage astrocytes and neurons. Previous studies showed that thrombin retracts processes on both astrocytes and neurons a process that, if controlled, could increase plasticity of these cells and contribute to repair processes (Gurwitz and Cunningham, 1988, 1990; Grand et al., 1989; Cavanaugh et al., 1990; Nelson and Siman, 1990). Thrombin is also mitogenic for astrocytes and induces the secretion of NGF and endothelin-1 from these cells (Ehrenreich et al., 1993; Neveu et al., 1993).

The use of synthetic agonist peptides which directly activate the thrombin receptor indicated that the protective effects of thrombin on astrocytes and neurons were receptor mediated. This strongly suggests that the protective functions of thrombin may be biologically important. The thrombin receptor is expressed in both neurons and astrocytes in various regions of rat 


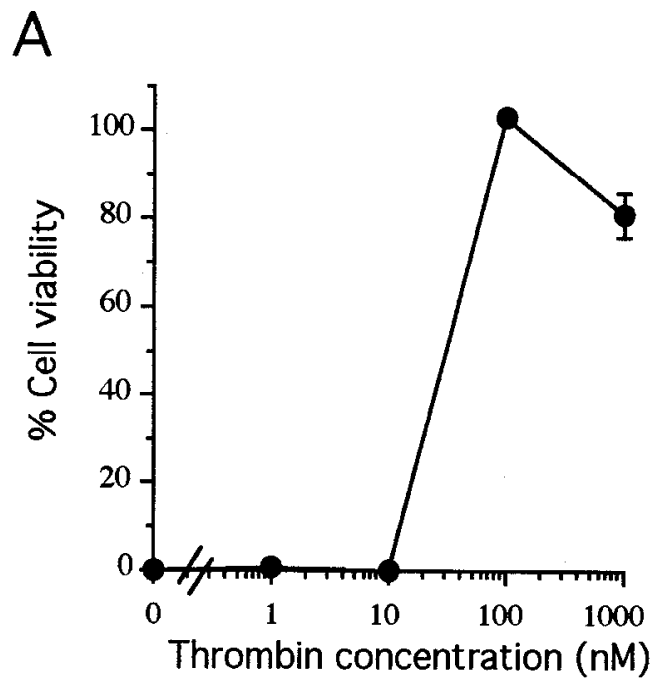

B
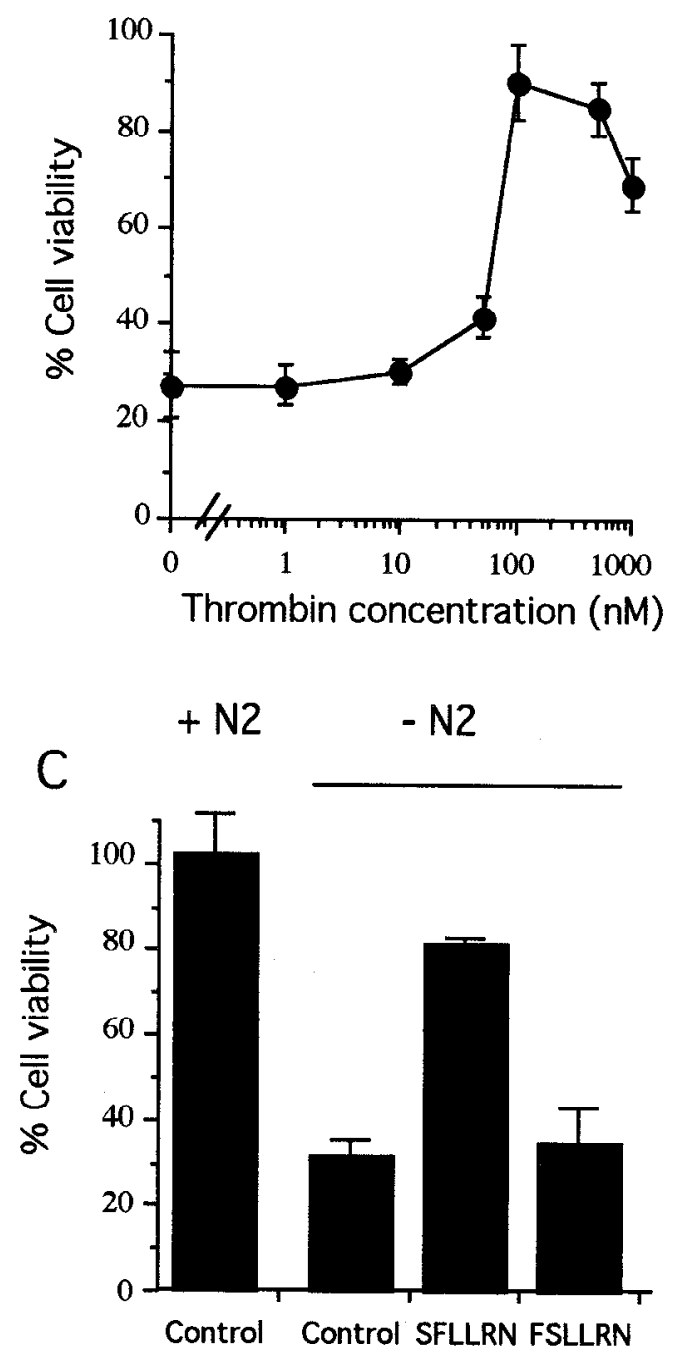

Figure 7. Thrombin and the thrombin receptor activating peptide protect rat hippocampal neurons from cell death produced by hypoglycemia and growth supplement deprivation. $A$, Dose-response curve for the protective effect of thrombin against hypoglycemia. Neurons that had been established for 1-3 d were incubated in medium containing 0.2 $\mathrm{mm}$ glucosc in the absence or presence of the indicated concentrations of thrombin. After $48 \mathrm{hr}$ cell viability was determined. $B$, Dose-response curve for the protective effect of thrombin against growth sup- brain (Niclou et al., 1994; Weinstein et al., 1995). It is noteworthy that the thrombin receptor is expressed at high levels in hippocampal pyramidal neurons (Weinstein et al., 1995), a par ticularly vulnerable population of neurons which undergoes selective degeneration following ischemia (Kirino, 1982; Meldrum and Garthwaite, 1990). The specific mechanisms by which receptor activation induces a protective effect remain to be determined. Thrombin is known to induce the synthesis of growth factors and cytokines from a number of cell types, so its protective effect could be mediated indirectly. However, evidence from this study suggests that thrombin's protective effect on astrocytes is mediated directly. First, the lowest concentrations of thrombin which protected astrocytes against cell death (1 pM to $100 \mathrm{pm}$ ) are much lower than those required to induce the synthesis of cytokines and growth factors (Harlan et al., 1986; Jones and Geczy, 1990; Okazaki et al., 1992; Neveu et al., 1993). Second, treatment of astrocytes with thrombin for as little as 1 hr prior to cell death induced a significant increase in astrocyte survival, indicating that thrombin's protective effect is induced very rapidly. Activation of the thrombin receptor induces a variety of signal transduction pathways resulting in stimulation of phospholipase $\mathrm{C}$, inhibition of adenylate cyclase, elevation of intracellular calcium, and activation of serine/threonine and tyrosine protein kinases (Van Obberghen-Schilling and Pouyssegur, 1993; Coughlin, 1994). These second messenger systems are differentially involved in the spectrum of cellular responses induced by thrombin. For example, we recently demonstrated that tyrosine kinase activity is required for the mitogenic effect of thrombin on astrocytes, but not for the reversal of stellation (Grabham and Cunningham, 1995). To further understand the cellular mechanisms that mediate the protective effect of thrombin, it will be important to identify the intracellular signaling events that are involved.

Although studies on cell survival following CNS injury have often focused on neurons, there is evidence that astrocytes may also be vulnerable following cerebrovascular injury in vivo (Giffard et al., 1990; Nedergaard et al., 1991; Chan-Ling and Stone, 1992; Juurlink and Hertz, 1993; Nieto-Sampedro, 1994; Sochocka et al., 1994). Since astrocytes are the major source of many of the known neurotrophic factors in the brain (Martin, 1992; Eddleston and Mucke, 1993; Mattson and Scheff, 1994) and are known to play an important role in the removal of toxic metabolites in the extracellular environment (Norenberg et al., 1988; Rosenberg and Aizenman, 1989; Sugiyama et al., 1989), the thrombin-mediated survival of astrocytes reported here may be important in minimizing neuronal degeneration following injury. It is noteworthy that the concentrations of thrombin required to protect astrocytes were lower than the concentrations required to prolect neurons. Although the reasons for this are not clear, astrocytes may be the first cells to contact thrombin

$\leftarrow$

plement deprivation. Freshly isolated neurons were plated in the absence of N2 supplements. One hour after plating the indicated concentrations of thrombin were added and cell viability determined after 48 hr. $C$, Protective effect of the thrombin receptor activating peptide. Freshly isolated neurons were plated in the absence of N2 supplements. One hour after plating the cells were either left untreated (control, $-N 2$ ) or $1 \mathrm{~mm}$ of the peptide SFLLRN or FSLLRN was added and cell viability determined after $48 \mathrm{hr}$. Control cultures were maintained in medium with $\mathrm{N} 2$ supplements throughout the experiment (control, $+N 2$ ). All values are the mean \pm SEM of triplicate samples. All studies were repeated in at least three independent experiments. 
A

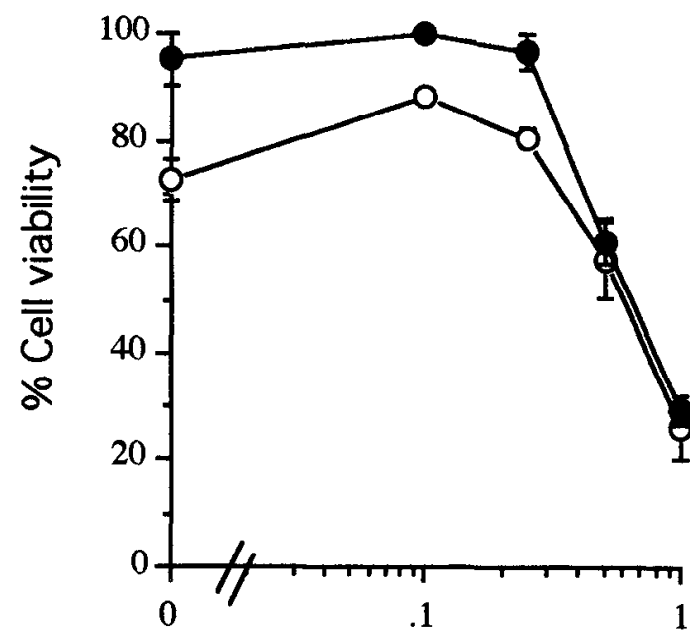

Thrombin concentration (UM)

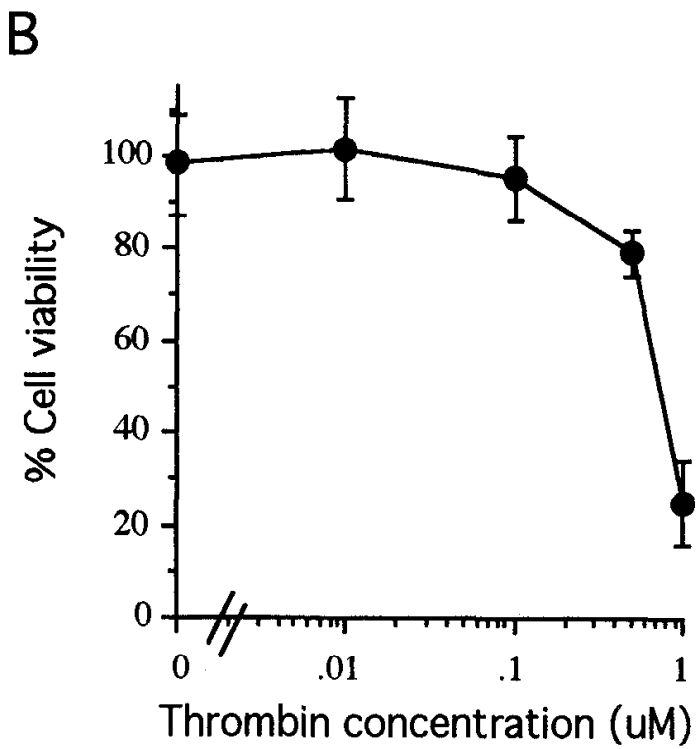

Figure 8. Thrombin kills rat neurons and astrocytes cultured under normal conditions. $A$, Differentiated $(O)$ or undifferentiated $(\Theta)$ rat astrocytes were incubated in medium containing $25 \mathrm{~mm}$ glucose in the absence or presence of the indicated concentrations of thrombin and cell viability determined $72 \mathrm{hr}$ later. All values are expressed as the mean \pm SEM of triplicate samples. All studies were repeated in at least three independent experiments. $B$, Rat hippocampal neurons were plated in medium containing $25 \mathrm{~mm}$ glucose and N2 supplements. Twentyfour hours after plating the cells were treated with the indicated concentrations of thrombin and cell viability determined $48 \mathrm{hr}$ later.

following breakdown of the blood-brain barrier. The importance of astrocyte survival in maintaining normal brain function is highlighted by recent evidence which suggests that astrocytes may play direct roles in memory and information processing (Cornell-Bell et al., 1990; Finkbeiner, 1992; Nedergaard, 1994; Parpura et al., 1994; Smith, 1994).

The protective effects of thrombin may be particularly crucial for astrocyte and neuronal survival in the early stages of CNS trauma. It is well established that several neurotrophic factors and cytokines can prevent neuronal degeneration and cell death mediated by a variety of environmental insults in vivo (Lindsay et al., 1994; Mattson and Scheff, 1994). However, expression of these protective factors in vivo is only increased in response to brain injury and significant time is required for their synthesis and secretion. In addition, several of these factors are released from microglia which are recruited to the site of injury relatively late in the response (Giulian, 1987; Berkenbosch, 1992; Mattson and Scheff, 1994). Thrombin is one of the first regulatory molecules generated at the site of injury and induces a rapid protective effect. The importance of rapidly inducing a protective effect following injury is highlighted by a recent study which showed that following ischemia the levels of glucose and oxygen decrease to nearly undetectable levels within $2 \mathrm{~min}$ (Silver and Erecinska, 1994). Since only a few minutes of exposure to such conditions can induce irreversible cell death, protective factors which are generated rapidly at the site of injury may be of critical importance.

Although liver is the primary site of prothrombin synthesis in the body, prothrombin mRNA has been detected in brain (Dihanich et al., 1991; Weinstein et al., 1995) and in cultured cells from the CNS (Dihanich et al., 1991; Deschepper et al., 1991). In weaning-age rats, prothrombin and thrombin receptor mRNAs are codistributed in certain late developing regions of the CNS suggesting that thrombin produced in the CNS might activate receptors on nearby cells (Weinstein et al., 1995). These results suggest that astrocyte and neuron viability may be regulated by thrombin produced in the CNS as well as thrombin that is produced from plasma prothrombin.

Regulation of thrombin activity following cerebrovascular injury may be critical to achieve optimal protection and to prevent potentially deleterious effects of thrombin. Since the concentration of prothrombin in plasma is about $1-5 \mu \mathrm{M}$, the local concentration of thrombin at sites of injury is potentially high. The present studies showed that there were optimal concentrations of thrombin that protected cultured astrocytes or neurons from metabolic insults. The protective effects declined at higher thrombin concentrations; these higher thrombin concentrations killed both astrocytes and neurons that were cultured under normal conditions. This undoubtedly reflects differential regulation of intracellular signal transduction cascades and gene expression by thrombin in stressed and non-stressed cells. Astrocytes surrounding capillaries contain much $\mathrm{PN}-1$ and appear well poised to inhibit excess thrombin (Choi et al., 1990). The importance of controlling thrombin after injury is underscored by findings that $\mathrm{PN}-1$, the primary thrombin inhibitor in brain, is upregulated following ischemic or excitotoxic injury to the brain (Hoffmann et al., 1992; Nitsch et al., 1993; Scotti et al., 1994) or following addition of injury-related cytokines to cultured neural cells (Cunningham et al., 1993; Vaughan and Cunningham, 1993). Since PN-1 can block both the protective and killing effects of thrombin, the balance between $\mathrm{PN}-1$ and thrombin may play an important role in regulating the viability of neurons and astrocytes following CNS injury or other conditions that alter the blood-brain barrier.

\section{References}

Baker JB, Low DA, Simmer RL, Cunningham DD (1980) Proteasenexin: a cellular component that links thrombin and plasminogen activator and mediates their binding to cells. Cell 21:37-45.

Bar-Shavit R, Kahn A, Fenton JW II, Wilner GD (1983) ReceptorInediated chemotactic response of a macrophage cell line (J774) to thrombin. Lab Invest 49:702-707. 
Beecher KL, Andersen TT, Fenton JW II, Festoff BW (1994) Thrombin receptor peptides induce shape change in neonatal murine astrocytes in culture. J Neurosci Res 37:108-115.

Berkenbosch F (1992) Macrophages and astroglial interactions in repair to brain injury. Ann NY Acad Sci 650:186-190.

Berndt M, Phillips D (1981) Platelet membrane proteins: composition and receptor function. In: Platelets in biology and pathology (Gordon J, ed), pp 43-74. Amsterdam: Elsevier/North Holland.

Bottenstein J, Sato G (1979) Growth of a rat neuroblastoma cell line in serum-free supplemented medium. Proc Natl Acad Sci USA 76: 514-517.

Carney DH, Glenn KC, Cunningham DD (1978) Conditions which affect initiation of animal cell division by trypsin and thrombin. $J$ Cell Physiol 95:13-22.

Cavanaugh K, Gurwitz D, Cunningham DD, Bradshaw R (1990) Reciprocal modulation of astrocyte stellation by thrombin and protease nexin-1. J Neurochem 54:1735-1743.

Chan-Ling T, Stone J (1992) Degeneration of astrocytes in feline retinopathy of prematurity causes failure of the blood-retinal barrier. Invest Ophthalmol Visual Sci 33:2148-2159.

Chen J, Ishii M, Wang L, Ishii K, Coughlin S (1994) 'Thrombin receptor activation: confirmation of the intramolecular tethered liganding hypothesis and discovery of an alternative intermolecular liganding mode. J Biol Chem 269:16041-16045.

Choi BH, Suzuki M, Kim T, Wagner SL, Cunningham DD (1990) Protease nexin-1: Iocalization in the human brain suggests a protective role against extravasated serine proteases. Am J Pathol 137:741-747.

Cornell-Bell AH, Finkbeiner SM, Cooper MS, Smith SJ (1990) Glutamate induces calcium waves in cultured astrocytes: long-range glial signaling. Science $247: 470-473$.

Coughlin SR (1994) Molecular mechanisms of thrombin signaling. Semin Hemat 31:270-277.

Cunningham DD, Pulliam L, Vaughan PJ (1993) Protease nexin-1 and thrombin: injury-related processes in the brain. Thromb Haemost 70 : 168-171.

Deschepper CF, Bigornia V, Berens ME, Lapointe MC (1991) Production of thrombin and antithrombin III by brain and astroglial cell cultures. Brain Res Mol Brain Res 11:355-358.

Dihanich M, Kaser M, Reinhard E, Cunningham D, Monard D (1991) Prothrombin mRNA is expressed by cells of the nervous system. Neuron 6:575-581.

Eddleston M, Mucke L (1993) Molecular profile of reactive astrocytes-implications for their role in neurologic disease. Neuroscience 54:15-36.

Ehrenreich H, Costa T, Clouse KA, Pluta RM, Ogino Y, Coligan JE, Burd PR (1993) Thrombin is a regulator of astrocytic endothelin-1. Brain Res 600:201-207.

Farmer L, Sommer J, Monard D (1990) Glial-derived nexin potentiates neurite extension in hippocampal pyramidal cells in vitro. Dev Neurosci $12: 73-80$

Finkbeiner S (1992) Calcium waves in astrocytes-filling in the gaps. Neuron 8:1101-1108

Gerszten RE, Chen J, Ishii M, Ishii K, Wang L, Nanevicz T, Turck CW, Vu TK, Coughlin SR (1994) Specificity of the thrombin receptor for agonist peptide is defined by its extracellular surface. Nature 368 : 648-651.

Giffard RG, Monyer H, Choi DW (1990) Selective vulnerability of cultured cortical glia to injury by extracellular acidosis. Brain Res 530:138-141.

Giulian D (1987) Ameboid microglia as effectors of inflammation in the central nervous system. J Neurosci Res 18:155-171.

Gloor S, Odink K, Guenther J, Nick H, Monard D (1986) A glia-derive neurite promoting factor with protease inhibitory activity belongs to the protease nexins. Cell 47:687-693.

Grabham PW, Cunningham DD (1995) Thrombin receptor activation stimulates astrocyte proliferation and reversal of stellation by distinct pathways: involvement of tyrosine phosphorylation. J Neurochem 64: 583-591.

Grand RJ, Grabham PW, Gallimore MJ, Gallimore PH (1989) Modulation of morphological differentiation of human neuroepithelial cells by serine proteases: independence from blood coagulation. EMBO J 8:2209-2215

Guenther J, Hanspeter N, Monard D (1985) A glia-derived neuritepromoting factor with protease inhibitory activity. EMBO J 4:19631966.
Gurwitz D, Cunningham DD (1988) Thrombin modulates and reverses neuroblastoma neurite outgrowth. Proc Natl Acad Sci USA 85:3440 3444

Gurwitz D, Cunningham DD (1990) Neurite outgrowth activity of protease nexin-1 on neuroblastoma cells requires thrombin inhibition. $\mathbf{J}$ Cell Physiol 142:155-162.

Harlan JM, Thompson PJ, Ross R, Bowen-Pope DF (1986) Alphathrombin induces release of platelet-derived growth factor-like molecule(s) by cultured human endothelial cells. J Cell Biol 103:11291133.

Hoffmann MC, Nitsch C, Scotti AL, Reinhard E, Monard D (1992) The prolonged presence of glia-derived nexin, an endogenous protease inhibitor, in the hippocampus after ischemia-induced delayed neuronal death. Neuroscience 49:397-408.

Hung DT, Vu TH, Nelken NA, Coughlin SR (1992) Thrombin-induced events in non-platelet cells are mediated by the unique proteolytic mechanism established for the cloned platelet thrombin receptor. J Cell Biol 116:827-832.

Jalink K, Moolenaar WH (1992) Thrombin receptor activation causes rapid neural cell rounding and neurite retraction independent of classic second messengers. J Cell Biol 118:411-419.

Jones A, Geczy CL (1990) Thrombin and factor Xa enhance the production of interleukin-1. Immunology 71:236-241.

Juurlink BH, Hertz L (1993) Ischemia-induced death of astrocytes and neurons in primary culture: pitfalls in quantifying neuronal cell death Brain Res Dev Brain Res 71:239-246.

Kirino T (1982) Delayed neuronal death in the gerbil hippocampus following ischemia. Brain Res 239:57-69.

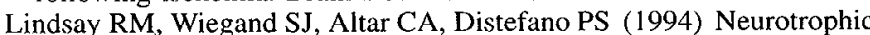
factors: from molecule to man. Trends Neurosci 17:182-190.

Loret C, Sensenbrenner M, Labourdette G (1989) Differential phenotypic expression induced in cultured rat astroblasts by acidic fibroblast growth factor, epidermal growth factor and thrombin. J Biol Chem 264:8319-8327.

Mann KG (1987) The assembly of blood clotting complexes on membranes. Trends Biochem Sci 12:229-233.

Martin DL (1992) Synthesis and release of neuroactive substances by glial cells. Glia 5:81-94.

Mattson MP, Scheff SW (1994) Endogenous neuroprotection factors and traumatic brain injury: mechanisms of action and implications for therapy. J Neurotrauma 11:3-33.

McCarthy KD, de Vellis J (1980) Preparation of separate astroglial and oligodendroglial cell cultures from rat cerebral tissue. J Cell Biol 85: $890-902$.

McGrogan M, Kennedy J, Li MP, Hsu C, Scott RW, Simonsen CC, Baker JB (1988) Molecular cloning and expression of two forms of human protease nexin-1. Biotechniques 6:172-177.

McNamara CA, Sarembock IJ, Gimple LW, Fenton JW II, Coughlin SR, Owens GK (1993) Thrombin stimulates proliferation of cultured rat aortic smooth muscle cells by a proteolytically activated receptor. J Clin Invest 91:94-98.

Meldrum B, Garthwaite J (1990) Excitatory amino acid neurotoxicity and neurodegenerative disease. Trends Pharmacol Sci 11:379-387.

Nedergaard M (1994) Dircet signaling from astrocytes to neurons in cultures of mammalian brain cells. Science 263:1768-1771.

Nedergaard M, Goldman SA, Desai S, Pulsinelli WA (1991) Acidinduced death in neurons and glia. J Neurosci 11:2489-2497.

Nelson RB, Siman R (1990) Thrombin and its inhibitors regulate morphological and biochemical differentiation of astrocytes in vitro. Brain Res Dev Brain Res 54:93-104.

Neveu I, Jehan F Jandrot-Perrus M, Wion D, Brachet P (1993) Enhancement of the synthesis and secretion of nerve growth factor in primary cultures of glial cells by proteases: a possible involvement of thrombin. J Neurochem 60:858-867.

Niclou S, Suidan H, Brown-Luedi M, Monard D (1994) Expression of the thrombin receptor mRNA in rat brain. Cell Mol Biol 40:421-428.

Nieto-Sampedro M, Mora F (1994) Active microglia, sick astroglia and Alzheimer type dementias. Neuroreport 5:375-380.

Nishino A, Suzuki M, Ohtani H, Motohashi O, Umezawa K, Nagura H, Yoshimoto T (1993) Thrombin may contribute to the pathophysiology of central nervous system injury. J Neurotrauma 10:167-179.

Nitsch C, Scotti AL, Monard D, Heim C, Sontag K-H (1993) The gliaderived protease nexin-1 persists for over 1 year in rat brain areas selectively lesioned by transient global ischaemia. Eur J Neurosci 5: 292-297. 
Norenherg M, Hertz. I, Schoushoe A, eds (1988) The hiochemical pathology of astrocytes. New York: Liss.

Okazaki H, Majesky MW, Harker LA, Schwartz SM (1992) Regulation of platelet-derived growth factor ligand and receptor gene expression by alpha-thrombin in vascular smooth muscle cells. Circ Res 71: 1285-1293.

Parpura V, Basarsky TA, Liu F, Jettinija K, Jeftinija S, Haydon PG (1994) Glutamate-mediated astrocyte-neuron signalling. Nature 369: 744-747.

Perraud F, Besnard F, Sensenbrenner M, Labourdette G (1987) Thrombin is a potent mitogen for rat astroblasts but not for oligodendrocytes and neuroblasts in primary culture. Int $\mathbf{J}$ Dev Neurosci 5:181-188.

Pike CJ, Burdick D, Walencewicz AJ, Glabe CG, Cotman CW (1993) Neurodegeneration induced by beta-amyloid peptides in vitro: the role of peptide assembly state. J Neurosci 13:1676-1687.

Rasmussen UB, Vouret-Craviari V, Jallat S, Schlesinger Y, Pages G, Pavirani A, Lecocq JP, Pouyssegur J, Van Obberghen-Schilling E (1991) cDNA cloning and expression of a hamster alpha-thrombin receptor coupled to $\mathrm{Ca}^{2+}$ mobilization. FEBS Lett 288:123-128.

Reinhard E, Meier R, Halfter W, Rovelli G, Monard D (1988) Detection of glia-derived nexin in the olfactory system of the rat. Neuron $1: 387-394$.

Reinhard E, Suidan, H, Pavlik A, Monard D (1994) Glia-derived nexin/ protease nexin-1 is expressed by a subset of neurons in the rat brain. $J$ Neurosci Res 37:256-270.

Rosenberg PA, Aizenman E (1989) Hundred-fold increase in neuronal vulnerability to glutamate toxicity in astrocyte-poor cultures of rat cerebral cortex. Neurosci Lett 103:162-168.

Scotti AL, Monard D, Nitsch C (1994) Re-expression of glia-derived nexin/protease nexin 1 depends on mode of lesion-induction or terminal degeneration: observations after excitotoxin or 6-hydroxydopamine lesions of rat substantia nigra. J Neurosci Res 37:155-168.

Silver IA, Erecinska M (1994) Extracellular glucose concentration in mammalian brain: continuous monitoring of changes during increased neuronal activity and upon limitation in oxygen supply in normo-, hypo-, and hyperglycemic animals. J Neurosci 14:50685076.

Smith SJ (1994) Neural signaling-neuromodulatory astrocytes. Curr Biol 4:807-810.

Sochocka E, Juurlink BH, Code WE, Hertz V, Peng L, Hertz L (1994) Cell death in primary cultures of mouse neurons and astrocytes during exposure to and 'recovery' from hypoxia, substrate deprivation and simulated ischemia. Brain Res 638:21-28.

Sugiyama K, Brunori A, Mayer ML (1989) Glial uptake of excitatory amino acids influences neuronal survival in cultures of mouse hippocampus. Neuroscience 32:779-791.

Suidan HS, Stone SR, Hemmings BA, Monard D (1992) Thrombin causes neurite retraction in neuronal cells through activation of cell surface receptors. Neuron 8:363-375.

Van Nostrand WE, Wagner SL, Cunningham DD (1988) Purification of a form of protease nexin 1 that binds heparin with a low affinity. Biochemistry 27:2176-2181.

Van Obberghen-Schilling E, Pouyssegur J (1993) Signaling pathways of the thrombin receptor. Thromb Haemost 70:163-167.

Vaughan PJ, Cunningham DD (1993) Regulation of Protease nexin-1 synthesis and secretion in cultured brain cells by injury-related factors. J Biol Chem 268:3720-3727.

Vaughan P, Su J, Cotman C, Cunningham D (1994) Protease nexin-1, a potent thrombin inhibitor, is reduced around cerebral blood vessels in Alzheimer's disease. Brain Res 668:160-170.

Vu TK, Hung DT, Wheaton VI, Coughlin SR (1991a) Molecular cloning of a functional thrombin receptor reveals a novel proteolytic mechanism of receptor activation. Cell 64:1057-1068.

Vu TK, Wheaton VI, Hung DT, Charo I, Coughlin SR (1991b) Domains specifying thrombin-receptor interaction. Nature 353:674-677

Wagner SL, Geddes JW, Cotman CW, Lau AL, Gurwitz D, Isackson PJ, Cunningham DD (1989) Protease nexin-1, an antithrombin with neurite outgrowth activity, is reduced in Alzheimer disease. Proc Natl Acad Sci USA 86:8284-8288

Weinstein J, Gold S, Cunningham D, Gall C (1995) Cellular localization of thrombin receptor $\mathrm{mRNA}$ in rat hrain: expression by mesencephalic dopaminergic neurons and co-distribution with prothrombin mRNA. J Neurosci 15:2906-2919. 